\title{
January Hath 31 Days: \\ Early Canadian Almanacs as \\ Primary Research Materials \\ Judy Donnelly
}

As the study of the past continues to intrigue the twentieth-century mind, scholars, librarians and archivists are constantly searching for information which will shed new light on how early Canadians lived, worked, learned and played. While books, newspapers, government documents and personal papers are in most cases the main sources consulted for this research, another genre of Canadiana, the almanac, also has much to contribute to our historical knowledge. American, British and French historians have chronicled the development of these annual publications in their countries with books such as Bernard Capp's English Almanacs 1500-1800: Astrology and the Popular Press, ${ }^{1}$ Marion Barber Stowell's Early American Almanacs: The Colonial Weekday Bible, ${ }^{2}$ and Geneviève Bollème's Les Almanachs Populaires aux XVII et XVIII Siècles: Essai d'Histoire Soci$a l e .^{3}$ That such a study has not been undertaken in Canada is due in large part to the difficulty in locating almanacs in this country, not only because of their highly ephemeral nature but also because of the unavailability of any comprehensive listing of Canadian almanacs. It is encouraging to report that a bibliography which will provide scholars with the locations and publishing histories of Canada's pre-I900 almanacs is well under way. ${ }^{4}$ In addition, the Canadian Institute for Historical Microreproductions ( Снім) has filmed almanacs as part of its Canadian Annuals Series, thereby providing national access to these often elusive publications.

As a preview to the bibliography, it is hoped that the following overview of Canadian almanacs will provide a new look at this fascinating genre which presents historical fact in such an interesting manner.

There is much speculation on the origin of the word 'almanac.' Stowell (whose research has provided the basis for much of the general history

Judy Donnelly is Project Librarian in the William Ready Division of Archives and Research Collections, Mills Memorial Library, McMaster University, where she is working on a bibliography of the publications of McClelland and Stewart. 
cited here) notes several possible sources, among them Samuel Briggs' observations that the Arabic almaneh means 'New Year's Gifts' and the Teutonic almaenachte meant 'observations on all the months,' while Ainsworth Spotford's conclusion was that the term came from the Arabic al-manah meaning 'The Reckoning.' Stowell's choice, and that of many other researchers, is that the word is derived from the Spanish Arabic al manakh meaning 'the count. ${ }^{\prime 5}$

Almanacs have been with us, in one form or another, since the second century A.D. when the Alexandrians prepared charts of the heavens which delineated the movements of the sun, moon, planets and stars. With the spread of Christianity, it became necessary to keep track of fast, feast and holy days. According to Stowell, ${ }^{6}$ the earliest Christian almanac was written in A.D. 354 on parchment, while Books of Hours and prayer books produced during the period I 200-I 600 included ecclesiastical calendars which resembled the almanacs in many ways. Providing a record of church festivals was also the main function of clog (also known as clogg or log) almanacs, which were square sticks approximately $2^{\prime \prime} \times 2$ " by one foot long. When held up to the sun, one could use them to determine the dates of church and royal feasts as well as the lunar cycle. These may have appeared in parts of Europe as early as the seventh century, and other evidence suggests that they were still being used in northern England in the late seventeenth century. ${ }^{7}$ The first almanacs were thus developed to answer both practical and spiritual questions, such as when to plant and when to pray.

With such a long history, it is not surprising to learn that almanacs were among the first items to be printed after the advent of moveable type. In I448, Gutenberg printed the Almanach auf das Jahr 1448, a sheet almanac. ${ }^{8}$ The first almanac in its more recognized form appears to be a Calendarium thirty-two pages printed in Nuremberg by Regiomontanus (Johann Müller) in I 474. ${ }^{9}$ Some twenty years later, England saw the publication of its first almanacs which were derivations of an earlier French almanac. ${ }^{10}$ This practice became a tradition, as almanac-makers frequently 'borrowed' from their competitors and from other publications as well. The first extant American almanac, compiled by Samuel Danforth and published in 1646 , preceded the publication of the first newspaper in America by some sixty-five years, ${ }^{11}$ a fact which emphasizes the importance of this genre in the study of everyday life in colonial America, and as a valuable resource in the study of the history of printing on this continent.

It is not surprising that American almanacs had a strong influence on those which were published in Canada, since so many of our first printers came to this country via the American colonies, and also because of the 
aforementioned practice of almanac makers pirating each other's work.

The first Canadian almanac, published in Quebec by Brown \& Gilmore for the year 1765, was entitled Almanac de Cabinet. ${ }^{12}$ Like Gutenberg's Almanach, this was a sheet almanac printed on one side of a large sheet of paper, broadside style, and was meant to be hung in the home or workplace for easy reference. Unfortunately, no copies have survived, and we know of its existence only through Marie Tremaine's diligent work in compiling her bibliography of pre-I80o Canadian imprints, and from an advertisement she cites which appeared in the Quebec Gazette on 24 January 1765 :

Les Imprimeurs viennent de publier L'Almanach de Cabinet pour l'année commune 1765, pour latitude de Quebec. Fait exactement par Monsr. Maurice Simonin, ancien Capitaine de Navire. Comme il n'a point été publié d'almanac de cette epéce en cette ville jusques à present, nous éspérons que le Succes de la Vente nous encouragera à en imprimer au commencement de chaque Nouvelle Année, en y ajoutant toujours quelque chose de nouveau. ${ }^{13}$

The first Canadian almanac to be issued in pamphlet form was the NovaScotia Calendar, published in Halifax by Anthony Henry for the year I769. ${ }^{14}$ Christopher Sower (or Sauer) Jr. emigrated from Philadelphia to Saint John and published what was not only New Brunswick's first almanac, but also its first 'book,' entitled an Astronomical Diary or Almanack for the Year of Our Lord Christ $1786 .{ }^{15}$ The first almanac known to have been printed in Upper Canada was Sylvester Tiffany's Upper Canada Almanac for $\mathrm{r} 800 .{ }^{16}$ In Charlottetown, George T. Haszard produced the inaugural Prince Edward Island Calendar for the Year of Our Lord 1829. ${ }^{17}$ Joseph Templeman compiled The Newfoundland Almanac for I84I ${ }^{18}$ which was probably the island's first publication of its kind. As Western Canada was settled and printing establishments were set up, almanacs soon followed. Cook \& Fletcher published a combination almanac and directory in the mid-r87os entitled (appropriately enough) Winnipeg Directory and Manitoba Almanac ... Postal Guide and Handbook of General Information. ${ }^{19}$ The first extant Saskatchewan almanac is the Regina Almanac, ${ }^{20}$ published by The Leader Co. for $\mathrm{I} 889$, while a year prior to this, the Calgary Tribune published an almanac. ${ }^{21}$ The Colonist Annual of I 885 , issued by the Colonist Printing \& Publishing Company in Victoria, was the first almanac to be printed in British Columbia. ${ }^{22}$ It is apparent that many of these almanacs were issued by local newspapers which had both the access to official information and the printing facilities necessary to produce such complex publications.

It is often difficult to estimate how many copies of an almanac were 
printed, but there are a few cases where print-runs are known. The Brown \& Gilmore sheet almanac was published in an edition of 300 copies, according to the Neilson papers at the National Archives of Canada. ${ }^{23}$ In I870, the wrapper of the very successful Miller's Canadian Farmer's Almanac, published by Robert Miller in Montreal, boasted a circulation of 35,000 copies. ${ }^{24}$ The average print-run was much lower, but quantities of 8,000 to Io,000 appear to be a reasonable estimate. Even these figures seem astounding to us today, and emphasize once again the popularity of this genre and its importance to its audience.

Almanacs were printed in languages other than French and English, and several examples of those produced in native languages are known. As early as I768, Brown \& Gilmore were producing an Indian Kalendar in the Montagnais dialect for Rev. Jean Baptiste de la Brosse. ${ }^{25}$ Iakentasetatha Kahnawakeha / Almanach Iroquois ${ }^{26}$ and Cree Almanack: Naheyowawe Pesimoo Mussinuhikum ${ }^{27}$ were both published in the late r 890 . There were also German-language almanacs, and Anthony Henry's Der Neuschottländische Calender of I 788 is thought to have been Canada's first German-language publication. ${ }^{28}$ Der Canada Calendar began publication in Berlin (Kitchener, Ontario) in the early I840s and was still being issued in $1920 .{ }^{29}$ Clearly, almanacs were attractive and necessary to a wide cross-section of the population.

What, then, did these almanacs look like? It was mentioned that the first almanac thought to be published in Canada was a sheet almanac. These were especially popular in Quebec where they continued to be published well into the nineteenth century. Often referred to as calendriers, they were issued primarily by newspapers. Copies of these sheet almanacs are particularly difficult to find, as they were probably viewed by their owners as being even more disposable than their pamphlet and pocket counterparts.

The pamphlet is the most familiar almanac form. Generally octavo or smaller in size, they were usually sixteen or thirty-two pages in length, and are often found with a hole punched in the upper corner so that they could be hung on the wall. They were usually issued in printed paper wrappers (often coloured), with an illustration on the cover.

'Pocket' almanacs were also popular. As their name suggests, they were small enough to be carried on one's person, although they frequently contained roo pages or more. To add to the longevity of the pocket almanac, often more care was taken with the binding. It is not uncommon to find them with marbled paper covers, or even in half or quarter leather. The publishers apparently offered their customers several choices. Moore's Pocket Almanac and General Register for 1789 is one such example. Wil- 
liam Moore advertised its prices in the Quebec Herald as follows:

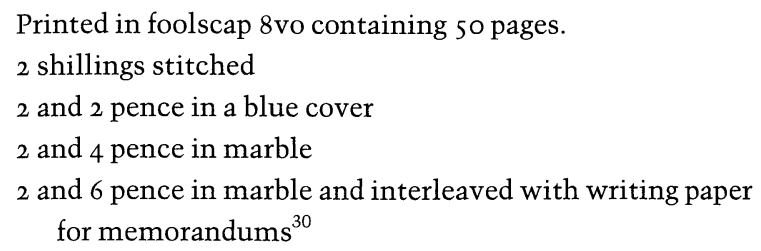

This last feature was also quite common in almanacs. These blank pages were often used by their owners as diaries, to record the weather, to keep track of household accounts, or even for more official notations. Several Atlantic almanacs were used to record the arrival and departure of ships from local harbours. ${ }^{31}$ A copy of an early Ontario almanac at the Archives of Ontario contains notes on the weather, crops, steamboat sailings, and a local potash works. ${ }^{32}$ Although the overall number of intact diaries is unfortunately few, those that have survived are a source of unique and interesting information.

Also noteworthy are the almanacs' illustrations. Most frequently, these took the form of agricultural vignettes which appeared on the title-pages or wrappers, and often on the calendar pages as well, where the Labours of the Months were faithfully reproduced. Another almanac standby is the Zodiac Man, or Man of Signs, a human figure surrounded by signs of the zodiac with each sign corresponding to a different part of the body. This figure dates from twelfth-century almanacs but could still be found in an I987 issue of the Canadian Farm and Home Almanac. ${ }^{33}$

Illustrations were not necessarily ornamental or astrological in nature; often they were used for educational purposes - for example, to explain astronomical data or to show the latest innovations in farming. Almanach des Cercles Agricoles ... 1898 contains drawings which demonstrate 'plombage du sol' and 'tomates protégés contre la gelée. ${ }^{\prime 34}$ Cartoons and caricatures were also popular, as were views of cities and important buildings. Advertising was uncommon in almanacs of the 1700 and early 1800 , but as it gained momentum during the nineteenth century, lavish drawings of storefronts and detailed renderings of products appeared in the almanac pages. These illustrations themselves are a wonderful resource for the study of architecture, agriculture, local and popular history.

The contents of almanacs were thus presented to their readers wrapped in decorative covers and embellished with wood cuts, engravings, and typographical ornaments. Contained within the pages are certain elements which are common to virtually all almanacs and which normally appear in 
the same order. Most almanacs begin with a preface which is usually selfdeprecating while at the same time boastful of the accuracy and uniqueness of the particular publication. The Nova Scotia Family Almanack and Register for 1851, for example, opens with the following statement:

Our ambition ... has been neither more nor less than to make this the best arranged, the most complete, and most perfect Almanack ever printed within the Province. ${ }^{35}$

The preface was also used on occasion to apologize for the late appearance of the almanac or for the necessity of omitting certain items owing to their unavailability at press time. Walter $\mathrm{H}$. Smith used the preface of his Smith's Planetary Almanac and Weather Guide to bemoan the lot of the almanac maker. In his issue for 1886 he wrote:

Many persons have an idea that there is a mint of money - a sort of gold mine ready to hand -in almanac making and weather forecasting. This is erroneous so far as my experience goes. To disabuse my readers' minds, what do they suppose I have gained from the last two annuals ... not fifty dollars. ${ }^{36}$

He continued in the same vein the following year:

Not one of my readers, I venture to say, would do so much for so little pecuniary return ... [however] when once a man takes hold of the weather subject with a view honestly to do his best to elucidate and reduce so vast a question to order, if he hopes to be at length successful there must be no relaxation of effort, no removing his hand from the plough; because the more he studies his subject the better he understands ... he has a reputation to maintain ... ${ }^{37}$

Having thus been assured of the almanac's accuracy and the laborious efforts which went into its production, the reader would then turn to the astrological information which usually followed the preface. In addition to the aforementioned Man of Signs, this section provided information on eclipses, morning and evening stars, planets, phases of the moon and other related information. Holidays and feast days would be listed as well. In Quebec and the Atlantic provinces, tide tables were also often included. Calendars, the original raison d'être of the almanacs, would follow this prefatory material. Normally the calendar would be preceded by explanatory notes which identified the symbols and abbreviations used by the almanac maker to represent the planets and their motions, astrological signs, etc. The calendar itself was divided into several columns in which was recorded such information as the changes of the moon, sunrise and 
sunset times, holidays, saints days, and of course weather prognostications. Historical events were often listed here as well, along with hints for farmers and homemakers, maxims, and other space fillers. As already mentioned, the upper portion of the calendar pages was often illustrated, most frequently with the Labours of the Months. Seasonal poetry of varying quality was also a common feature of the calendar. Christopher Sower's An Astronomical Diary, or Almanack for ... 1786 offers a wry comment on both almanac verse and weather prognostications in the introductory stanza to a long pastoral poem entitled 'Amanda':

\author{
Must I appear in white and black \\ To aid New Brunswick Almanack; \\ With trimmed and tortur'd lines engage \\ To fix four lines upon a page. \\ Come then, I'll try, but will forbear \\ The freezing horrors of the year... ${ }^{38}$
}

Beyond these components - that is, a preface, astrological data, explanatory notes and the calendar - the contents of almanacs varied widely. Generally speaking, they may be divided into three main categories: official information, information that pertained to the day-to-day lives of the readers, and entertainment. Official information may be further subdivided into two sections: people (that is, lists of government officials, professionals, and service providers) and regulations (new legislation, tariffs, local by-laws, etc.).

The 'people' component is a particular strength of almanacs, and one which greatly enhances their value as primary research materials. This information was presented in the almanacs in the form of civil and military registers and other lists which identified a wide variety of people. As a rule, the lists appeared in order of rank, i.e., beginning with the British monarchy and ending with municipal officers such as clerks, assessors, inspectors, and commissioners. An extraordinary amount of information may be gleaned from these detailed sections of the almanacs. For example, Belcher's Farmers Almanac for 1853, published in Halifax, includes the names of two 'Inspectors and Weighers of Fresh Beef and of Pickled Beef and Pork,' three 'Surveyors of Brick and Lime and Measurers of Mason's Work,' and 'The Keeper of the Powder Magazine. ${ }^{39}$ We also learn from this municipal list that 'The Police Office is open every weekday from Io till 4 o'clock' and that 'One of the Aldermen presides weekly in rotation.' The illustration which Belcher has chosen to appear over the main heading for this section, 'The Corporation of the City of Halifax,' is also elucidating: it depicts an obese figure clutching a knife and fork, with what appear to be 
liquor bottles close at hand. In the almanac, the compiler's personal comment could find its way into something even as innocuous as a municipal list.

These civil lists were normally followed by information on courts and the judiciary, including court sessions and circuit court schedules. Detailed lists of sheriffs, judges, clerks, barristers, solicitors, attorneys, and notaries were also provided, thus making the almanac a rich resource for the study of the law profession.

Another important component of early almanacs was the military list which, again, was usually quite detailed. This could include British army and naval officers, military staff, and, perhaps of most value to the historian, the militia. Such a list in The Upper Canada Almanac and Provincial Calendar for ... 1831 includes the regiments, ranks, and dates of commissions of several noted Canadians, among them Samuel Strickland, James Lesslie, and members of the Ridout family. ${ }^{40}$ Manuscript notes are often found on these lists as the almanac owners updated them, made a mark beside their own names, or recorded a particular incident. An example in a copy of the above named Upper Canada Almanac confirms that Lieutenant 'Ludovick Weidman,' whose name the owner has marked with an ' $x$,' was 'killed on the rebel's side at Gallow's Hill, 6 Dec. ' 37 ... the only man killed.... ${ }^{41}$ It is quite evident that these military lists are valuable to researchers as varied as the genealogist and the military historian.

There are numerous other groups of people who were documented in almanacs, including physicians, coroners, surveyors, land agents, river pilots, and firewardens. Teachers and clergymen were frequently listed as well, usually in the context of the school or church with which they were affiliated. Information pertaining to charitable institutions, societies, clubs, and lodges was also included. An I830 Montreal almanac, for instance, records a group known as the 'Quebec Charitable Institution for the Suppression of Street Begging, and Supply of Work to the Poor. ${ }^{42}$ The reader could consult an almanac to see who directed and belonged to these groups, and also to determine, for example, that the 1828 meetings of the 'Orphan's Friend' lodge would be held at St. Stephen's, N.B. the ' $2 \mathrm{~d}$ Wednesday after every Full Moon, ${ }^{43}$ and that in I 829 , Saint John boasted a cricket club. ${ }^{44}$

The aforementioned examples are but a brief sampling of the type of information generally contained in the 'people' lists of the almanacs. It should be evident from this limited selection that the documentation of individuals from many walks of life contributed greatly to the almanacs' value.

As already mentioned, there is another aspect to the official information provided by these annual publications. It was common practice for the 
almanac makers to publish extracts from legislation passed by different levels of government during the previous year. Naturally, these regulations could affect the livelihood of the readers, as in the cases of the fish and game laws which were published in Quebec almanacs, and the acts relating to gold mining which were included in The British Columbia Almanac in the r89os /'Every free miner shall ... have the right to enter, locate, prospect, and mine upon any waste lands of the Crown for all minerals other than coal...' $\mid .^{45}$ Local by-laws were also outlined, as for example in a Montreal almanac which contains 'Rates and Regulations Regarding Chimney Sweeping. ${ }^{46}$ The Almanach de Quebec pour ... 1783 published the following instructions:

Persons living in the Lower-town shall cause ... dirt and rubbish ... to be removed within twenty-four hours, and laid on the beach at low water mark, between Mr. Willock's Wharf and the stone pier at the Canoterie. ${ }^{47}$

This same almanac lists another local regulation which gives us a wonderful glimpse into eighteenth-century life in Quebec:

Any person may seize and confine any hog found in the streets, and he shall employ the Bellman immediately to publish in the principal streets, but particularly in the street where he took up the hog, that he is ready to deliver it to the owner on his paying Io shillings and all charges ... ${ }^{48}$

Cartage rates were commonly listed in almanacs as well. The rates which precede the above regulations inform us that the fee to haul a cord of wood from the Lower-town to the Upper-town was 'two shillings and six pence,' while nearly Ioo years later in Ottawa the cost of a 'one horse vehicle for the first hour' was $\$ 0.75 .{ }^{49}$ Tariffs and trade figures were also commonly listed in the almanacs and are a fascinating source of information. In 1860 , for example, 695,9 5 lbs. of tea were imported to Newfoundland, ${ }^{50}$ and in I 856 a 'List of Vessels In and Out of Newfoundland' records the following: 'From Denmark; 2 in; 4 I I tons; I9 men. ${ }^{\text {,51 }}$

Detailed postal information was another common feature of almanacs. Postal rates and regulations as well as lists of post offices and names of postmasters were provided. Telegraph rates were also supplied. Transportation was another favourite and essential topic covered by the almanacs. Roads, distances, inns, and stagecoach times were provided by many almanacs. Belcher's Farmer's Almanack for ... 1841 informs us that the 'Royal Eastern Stage Coaches (carrying H.M. Mails,) runs three times in the week from Halifax to Pictou and vice versa' and that the distance from the Widow Purley's to Fredericton was I 2 miles. ${ }^{52}$ As transportation 
improved, canal, steamship, and railway information was listed and could include anything from fares and regulations to annual statistics on usage and the number of miles of railroad constructed. Thus we learn from an I 882 Saint John almanac that a first class ticket from that city to Bangor, Maine cost $\$ 5.00,{ }^{53}$ while The Canadian Mercantile Annual for I 874 informs us that the 'Coburg, Peterboro' \& Marmora' rail line consisted of 28 miles of track and grossed $\$ 7,293$ for the month of September I $872 .{ }^{54}$

These are only a few examples of the types of lists, regulations, and statistics which can be found in Canada's early almanacs. The practice of providing official information is one that has persisted into the twentieth century; most of the almanacs still being published are produced for this reason alone.

In addition to these weighty, modern reference tools, another type of almanac continues to be published today. This is the farmer's almanac which owes its existence to another strong tradition of the genre, that being the provision of day-to-day information. Weather prognostications, agricultural hints, recipes, and remedies have long been almanac staples. Examination of these elements of the almanacs gives a clear picture of what was important in the lives of early Canadians, what they needed to know about on a daily basis, and under what conditions they lived. They relied on the almanacs to provide them with this type of information, since often it was not available elsewhere. Some almanacs give detailed planting schedules and reports on new crops and techniques for farmers and gardeners. Bryson's Canadian Farmer's Almanac for ... 1849, for example, contains rules for ploughing and crop rotation and articles on fertilizing and guano. ${ }^{55}$ The Upper Canada Farmers' and Mechanics' Almanac ... 1840 explains how to combat wheat fly and lists 'Things a Farmer should not do,' among them, 'A farmer should shun the doors of a bank as he would the approach of the plague or cholera ... ${ }^{56}$

The recipes which were quite commonly included were not only for such delicacies as horehound candy, ice cream, and ginger beer, but also for household items such as paint, dyes, ink, cement, and disinfectants. Since the almanac frequently served as both doctor and veterinarian, remedies for human and animal ailments were often given. The 1870 issue of the successful Miller's Canadian Farmer's Almanac includes recipes for an antidote to snake poison and instructions on the use of carbolic acid as a cure for foot-rot in sheep. ${ }^{57}$ Readers of The British American Almanack ... 1792 were given a choice of remedies to cure 'a putrid sore throat':

Gargle with an infusion of SAGE in warm VINEGAR, sweetened with MAPLE SUGAR; - or, with red PORT WINE made warm and sweetened with the same, or MolAsses. - Drink also of Port Wine and eat Carrot Pudding. ${ }^{58}$ 


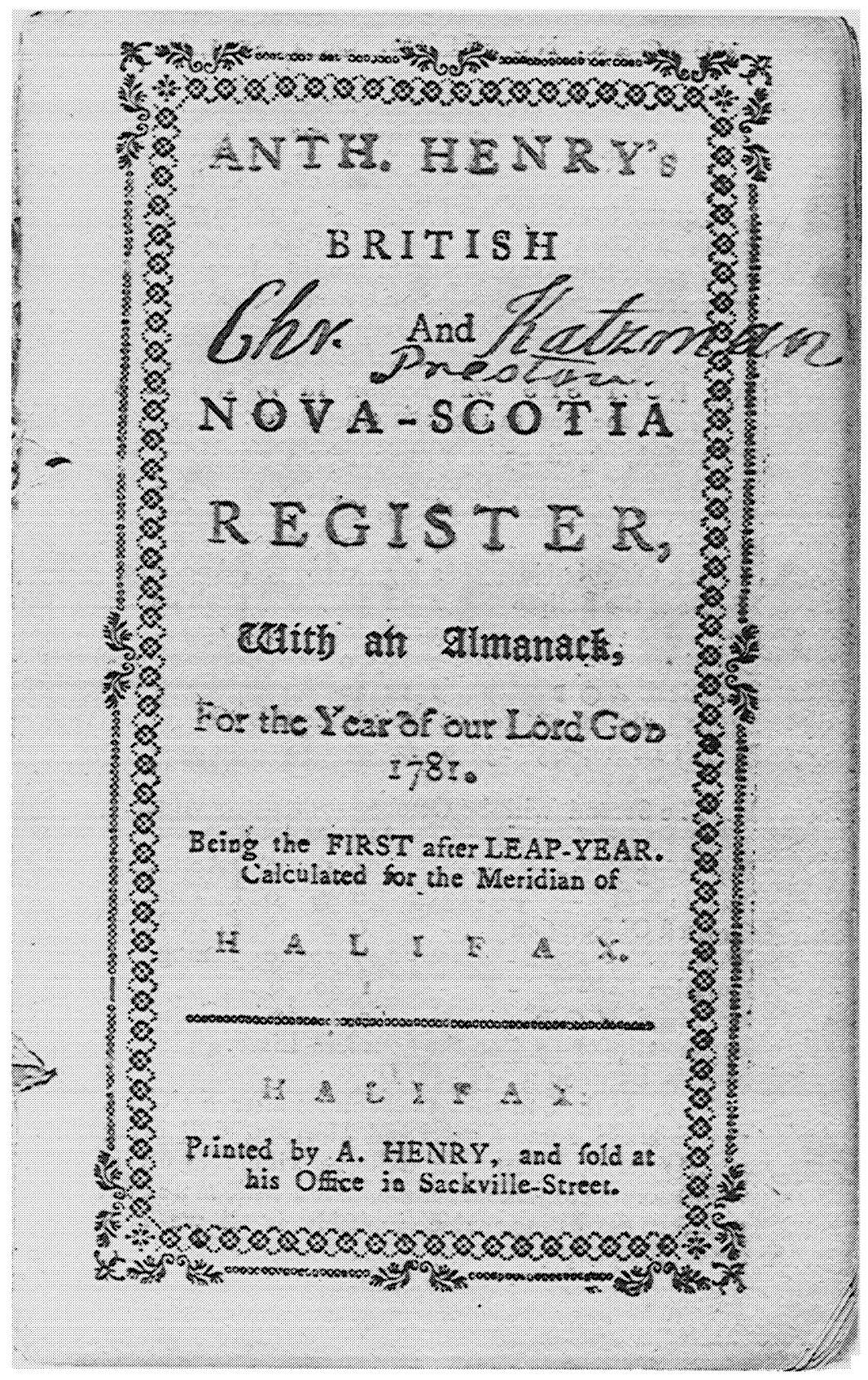

(Photograph courtesy of the Lawrence Lande Collection, Department of Rare Books and Special Collections, McGill University Libraries.) Lande SIO5 8 . 


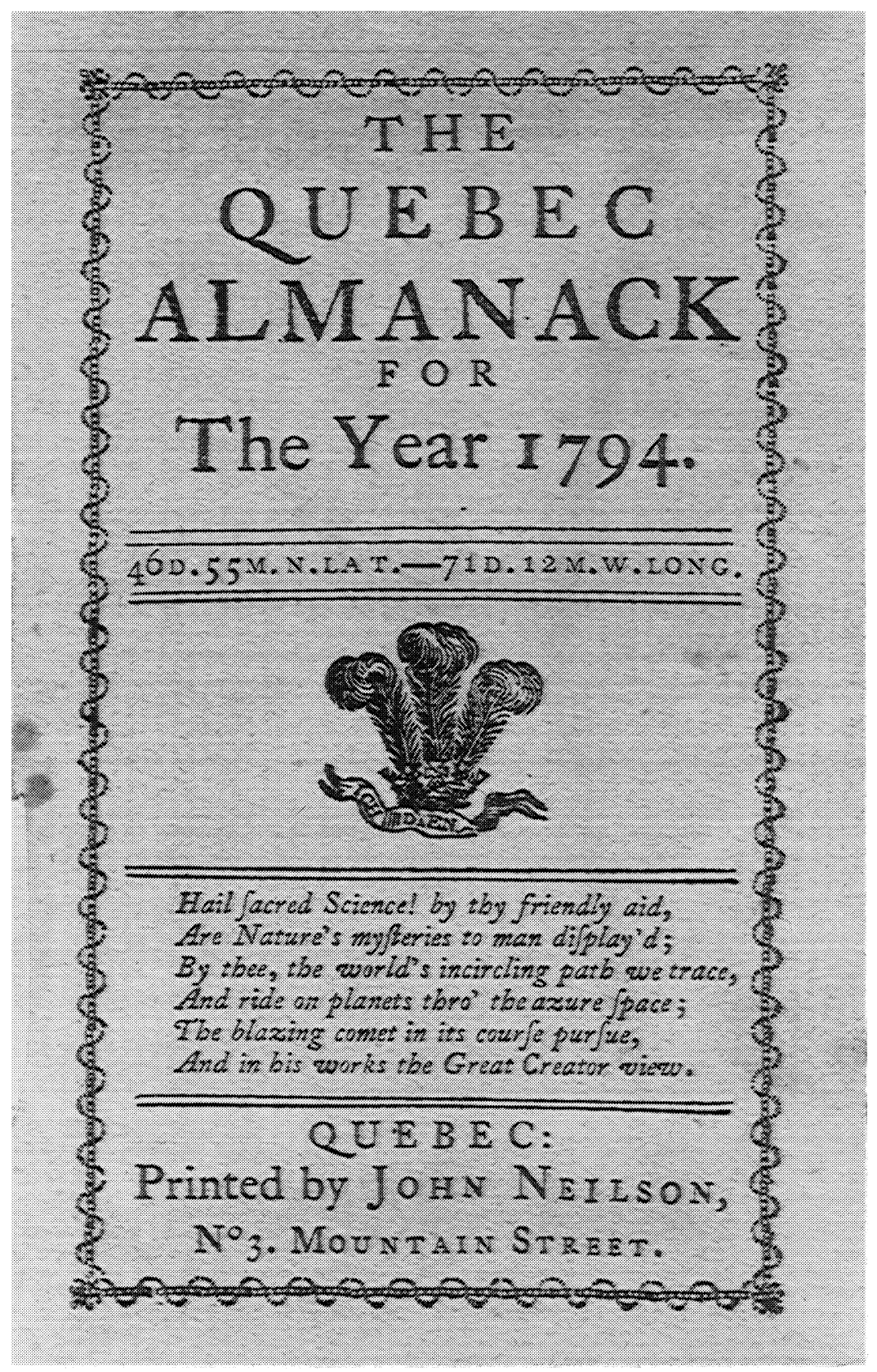

(Photograph courtesy of the Lawrence Lande Collection, Department of Rare Books and Special Collections, McGill University Libraries.) Lande 95. 


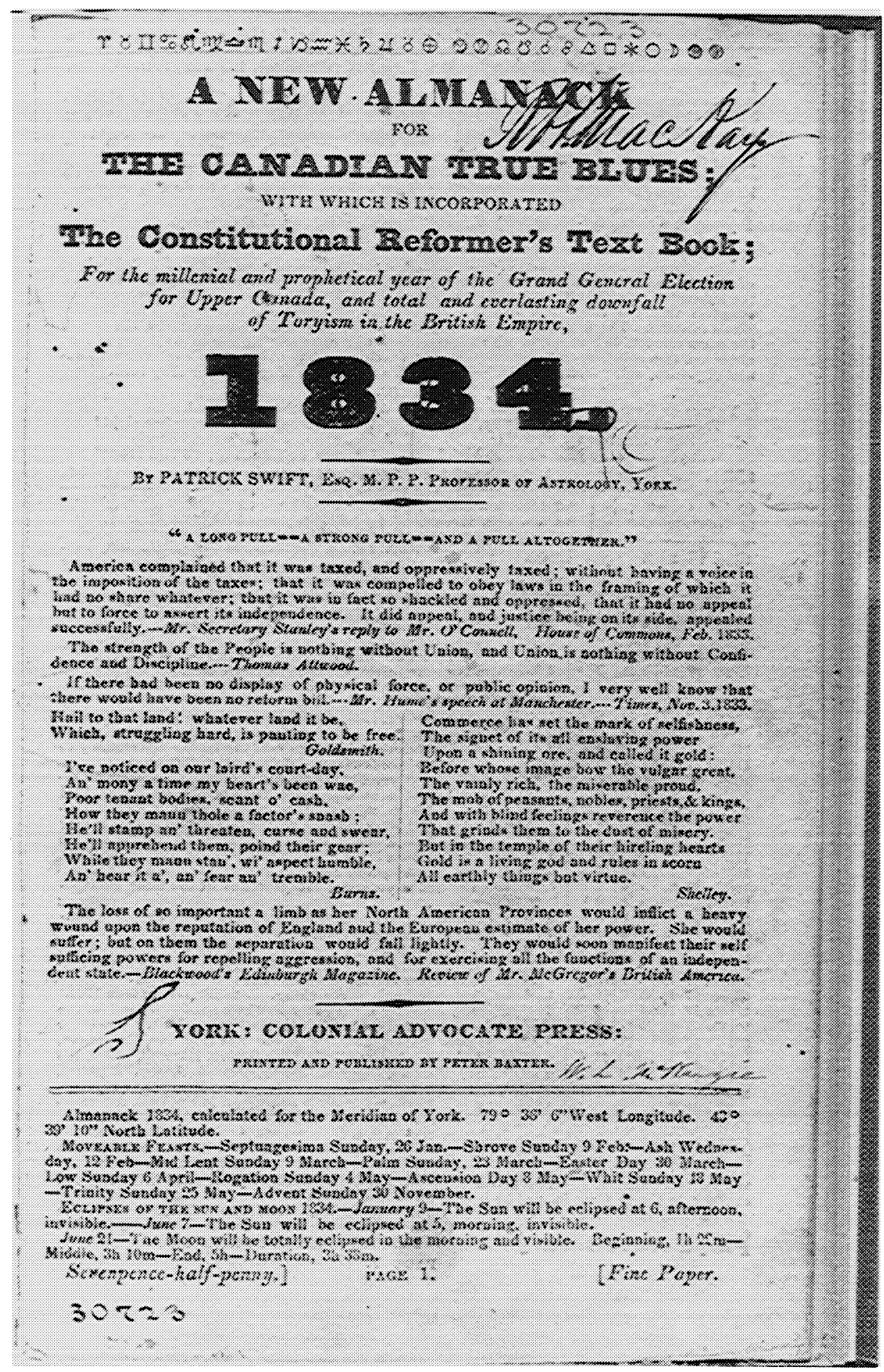

(Photograph courtesy of the Lawrence Lande Collection, Department of Rare Books and Special Collections, McGill University Libraries.) Lande $\mathrm{S}_{32}$. 


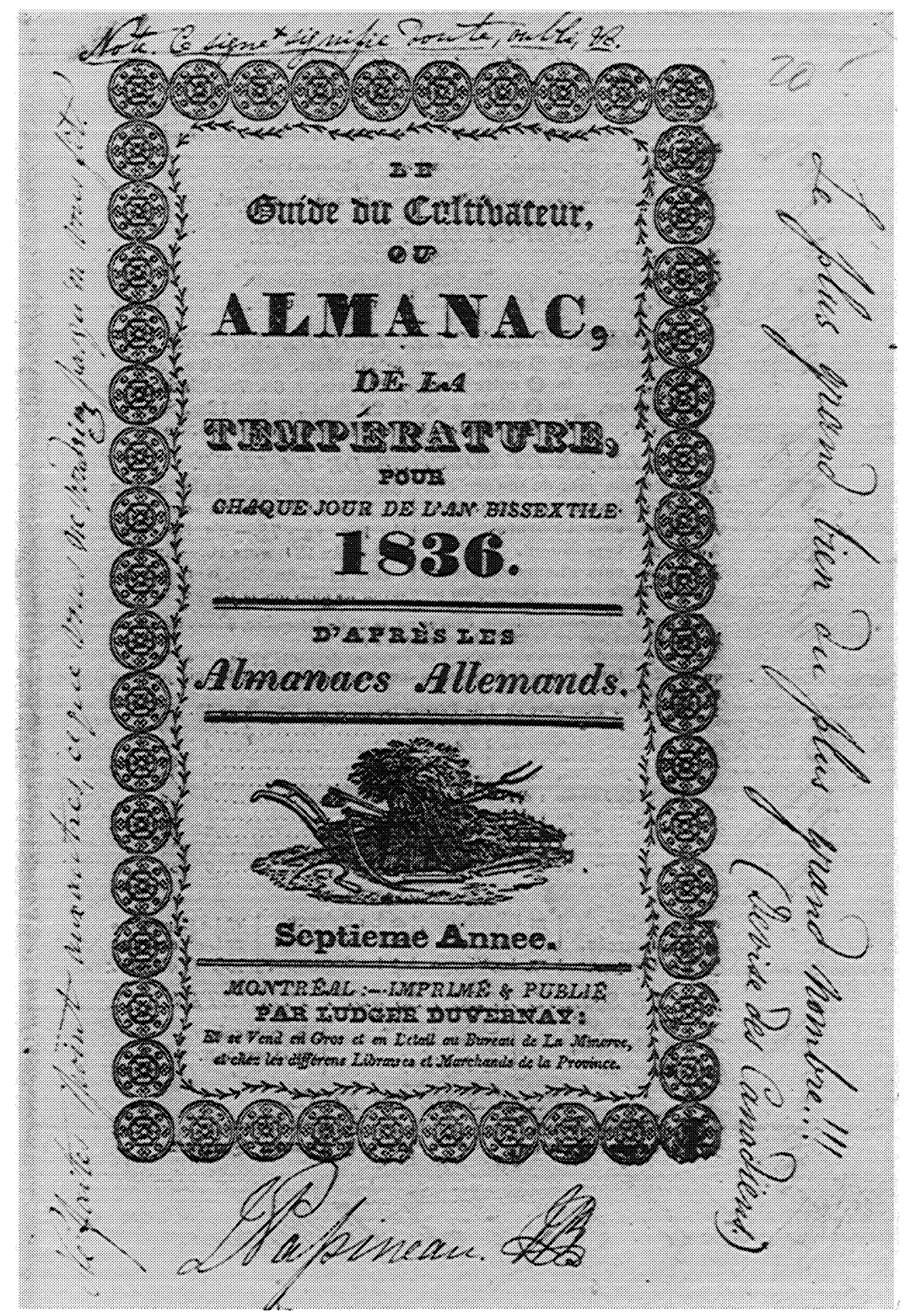

(Photograph courtesy of the Lawrence Lande Collection, Department of Rare Books and Special Collections, McGill University Libraries.) Lande S395. 


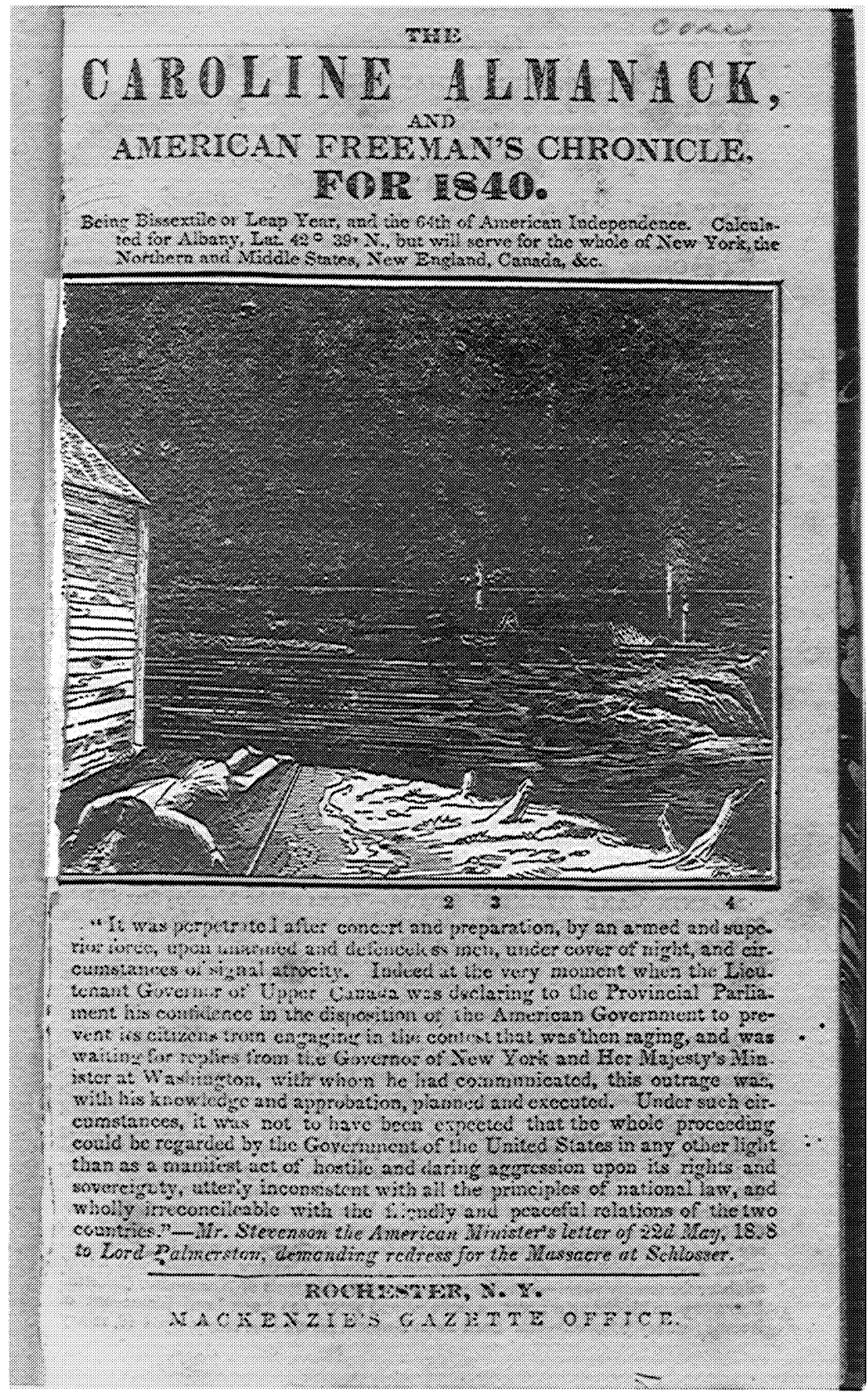

(Photograph courtesy of the Department of Rare Books and Special Collections, McGill University Libraries.) 


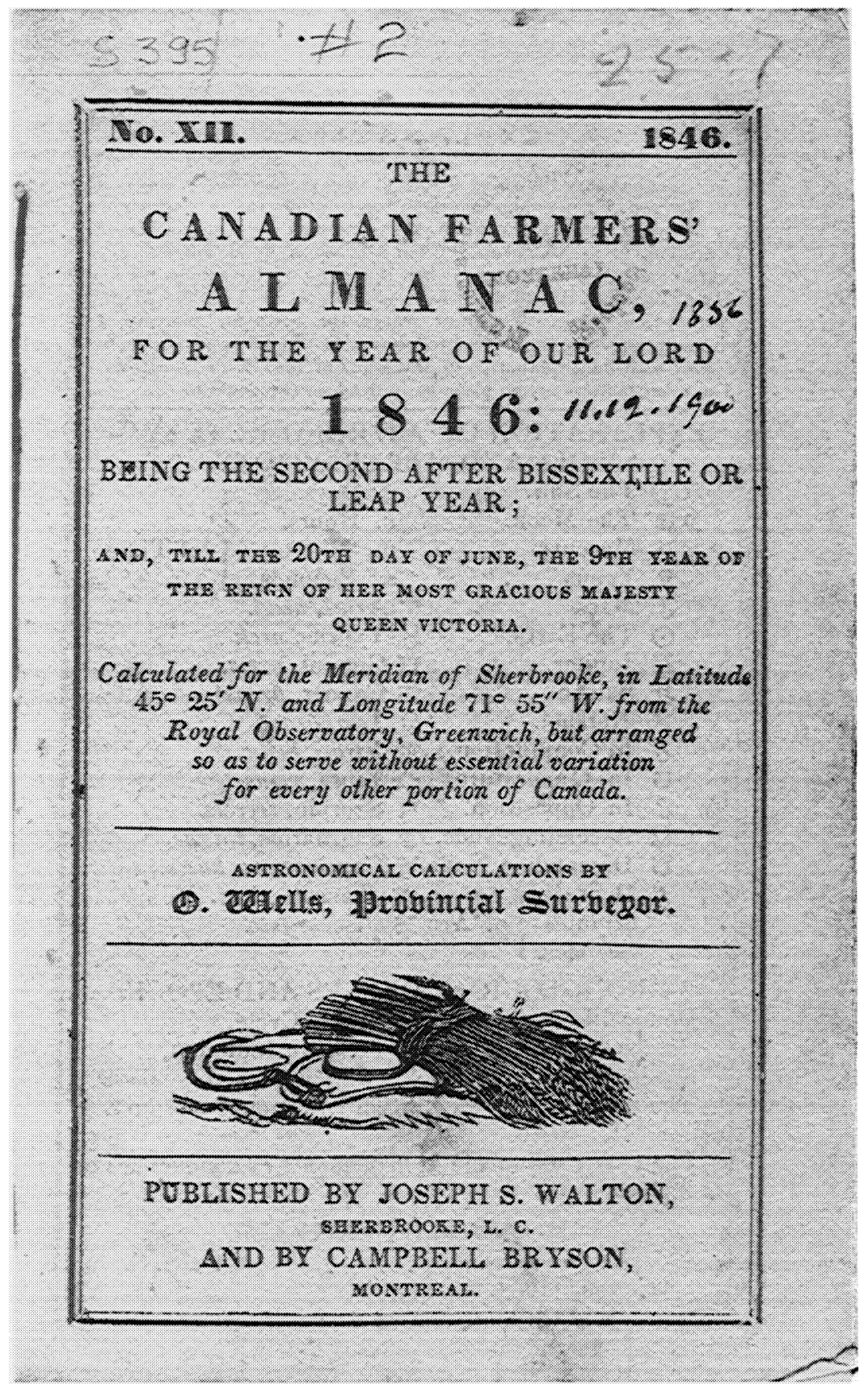

(Photograph courtesy of the Lawrence Lande Collection, Department of Rare Books and Special Collections, McGill University Libraries.) Lande S696. 


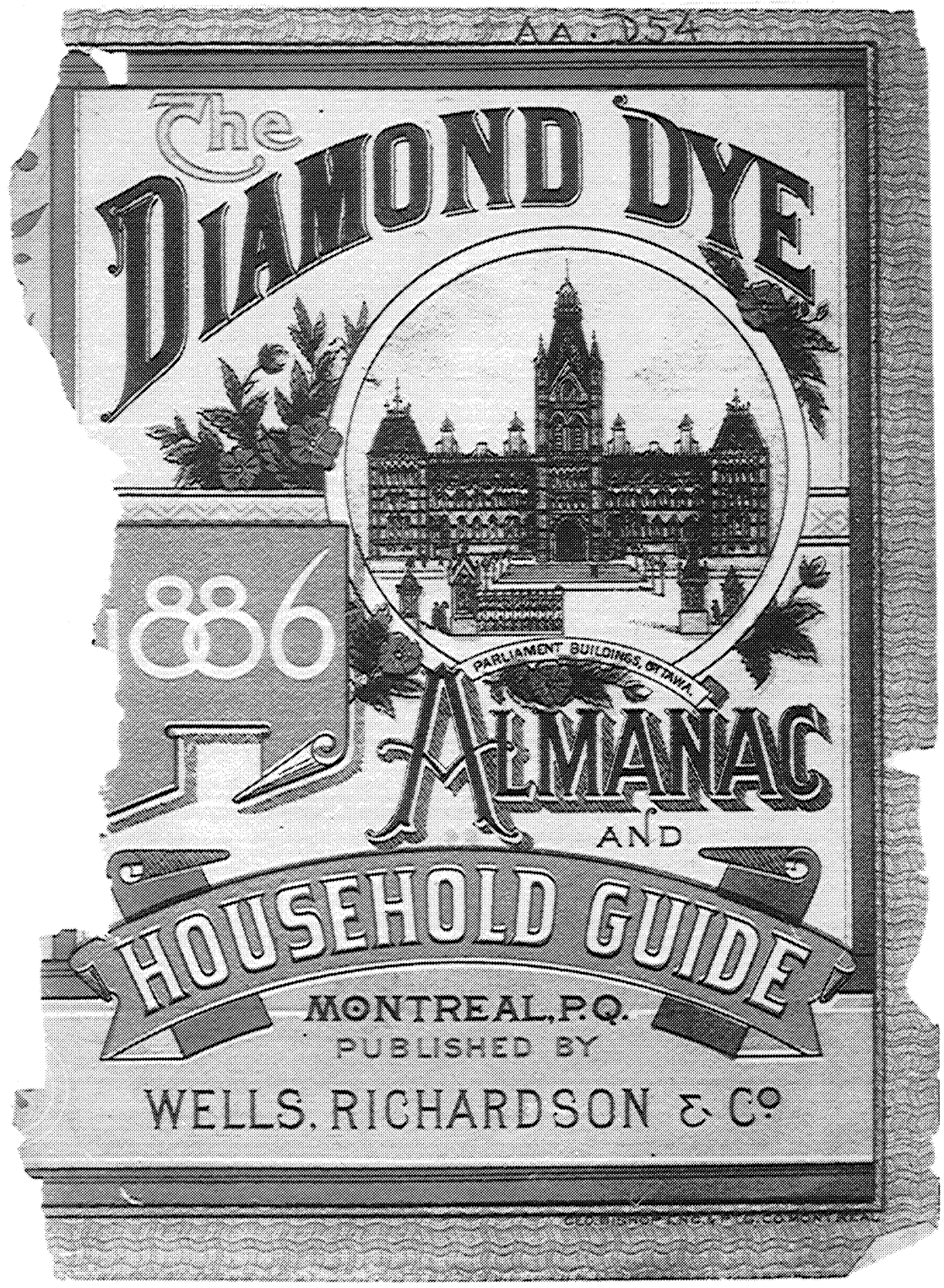

(Photograph courtesy of the Department of Rare Books and Special Collections, McGill University Libraries.) 


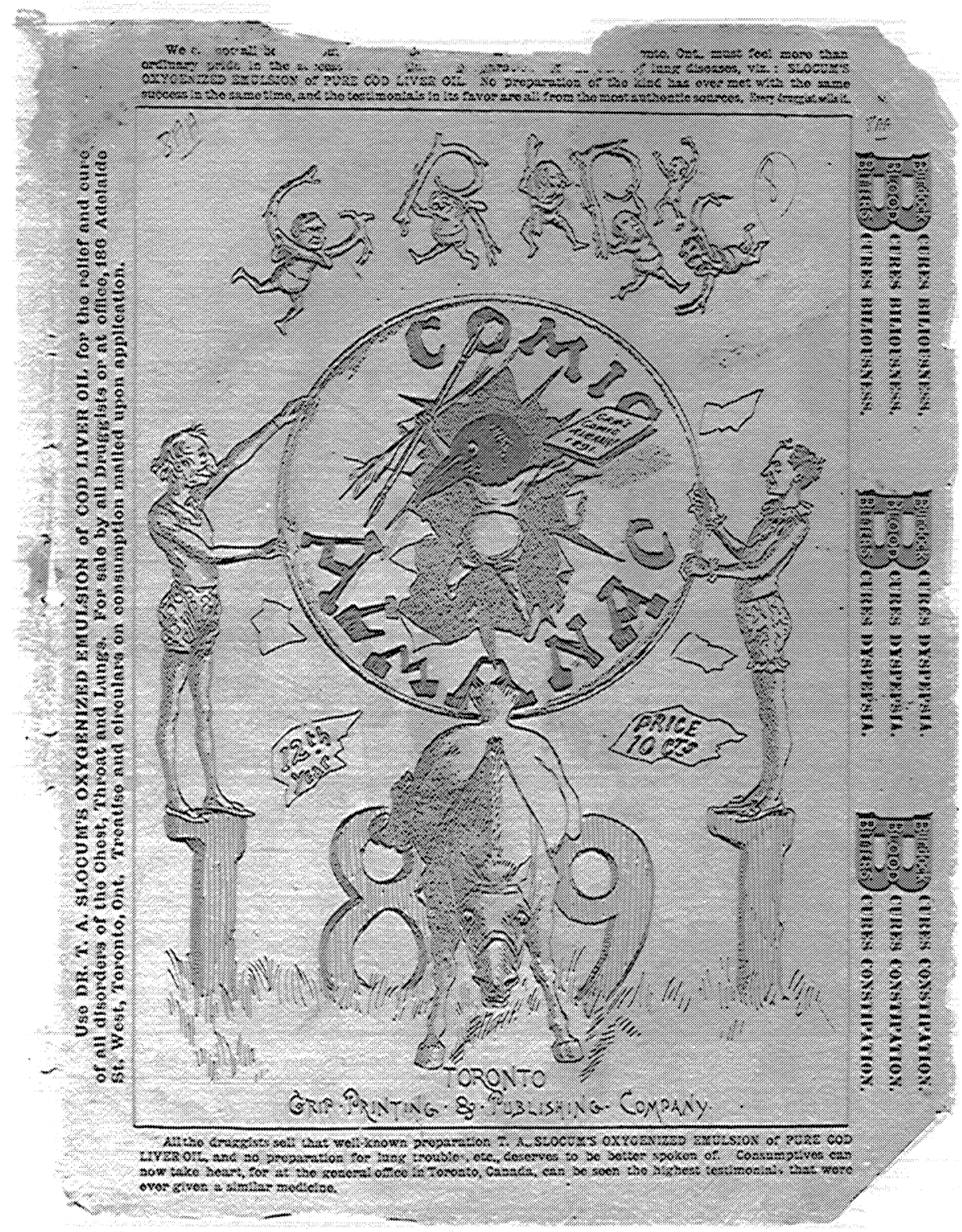

(Photograph courtesy of the Lawrence Lande Collection, Department of Rare Books and Special Collections, McGill University Libraries. Arkin Collection.) 
Not all of the cures were so pleasant. The Canadian Family Almanac ... 1893 recommends the following combination for a toothache: 'I oz. alcohol, 2 drachmas cayenne pepper, I oz. kerosene oil. ${ }^{\prime 59}$ This is but one example wherein the remedy seems worse than the ailment. However, the ingredients for these concoctions are not only interesting and at times amusing; they also tell us what foodstuffs and other staples would have been commonly available to Canadians at that time, thereby offering us a look into the pantries and medicine chests of our ancestors.

Aside from recipes, mathematical tables were another mainstay of almanacs and were provided for such purposes as currency conversion, the calculation of interest or wages, and weights and measures. Since almanacs reached many segments of the population, many of whom may have had little formal education, this type of information would have been extremely helpful in carrying out daily activities.

Lest it be thought that almanacs were all work and no play, one of their most interesting aspects is the role they took in providing entertainment to their readers. All types of literature can be found in almanacs, including short stories and anecdotes, biographies, histories, poetry, and of course the ever present maxims, for which almanacs are well known. 'True merit is like a river; the deeper it is the less noise it makes,' we are told in the I 842 issue of the Montreal Almanack. ${ }^{60}$ While the message in this literature was often serious and moralizing, just as frequently it was of a comic or even bawdy nature, as this I 825 example shows:

Tom call'd his friend a pimp, forsooth,

When warm engaged in strife,

Said Will, 'I can't deny the truth,

But curse your tattling wife ${ }^{\prime 61}$

Much of the literary work in the almanacs was 'borrowed' from other sources, but some appears also to have been written specifically for the almanac in question. Identifying these original Canadian works would be an interesting and challenging task for a literary historian.

Aside from literature, the almanacs contained other items to amuse their readers. Cartoons and caricatures have been mentioned before and were used not only for light entertainment, but also for political comment, as was evidenced by the rotund figure Belcher used to represent the Halifax city council. Other wonderful examples appear in the issues of the People's Almanac published by the Montreal Gazette in the early i 890 , which contained numerous anti-free trade cartoons. In addition to humorous illustrations, there were often puzzles, tongue twisters and brain teasers to solve, and the clever almanac maker waited until the following year to 
divulge the solutions. Jokes were a mainstay of many almanacs, and some prove to be timeless, as in this example from a Quebec almanac, Etrennes Mignones [sic] pour ... 1799:

Un avocat légua par testament tout son bien aux foux, aux enragés et aux imbéciles. On lui en demanda la raison- Pour le rendre à ceux de qui je le tiêns. $^{62}$

Music was another form of entertainment provided by several almanac makers, among them Alex McGibbon, whose Dominion Almanac for 1868 contains the words and music for 'Hurrah for Canada!' composed by G. W. Johnson of Binbrook, Ontario. ${ }^{63}$ As in the case of the literary selections, it would be interesting to document the original Canadian compositions found in the almanacs' pages. It is perhaps worth noting at this point that not every almanac contained all of these elements. While there were certain standard features, the degree to which topics were covered depended upon the type of almanac in question. To assure a wide readership, most compilers did include a variety of information. There were several genres of almanacs, however, which emphasized specific subjects and which were thus primarily intended for particular segments of the population. The farmer's almanac is one which is well known to us even today. Mercantile almanacs were common as well, and would include extensive details relating to customs and tariffs, trade figures, banking, financial statistics, and so forth, for the business community. Nautical almanacs were, as one would expect, a speciality of the Atlantic provinces and provided such crucial information as navigational directions for entering harbours and channels, lighthouse locations and signals, harbour signals, dockage fees, and guides to the flags of local private merchants' vessels.

Other almanacs were produced primarily to entertain their readers. The focus could be on literature, illustration, humour, or a bit of all three as in the case of the popular annual of Toronto's Grip Printing and Publishing Co., Grip's Comic Almanac, which contained humorous anecdotes, poems, and cartoons which often poked fun at the politicians of the day. The cover for the I 890 issue, for example, is illustrated with the signs of the zodiac; in this case, however, noted politicians are used in place of the usual astrological animals and figures. Similarly, the introductory pages of an earlier issue contain a passage entitled 'Grip's Horror-Scope [sic] for I $888^{\prime}$ which includes this prediction:

The month of January will be marked by two days of tropical weather, especially the 4th, when many large bills fall due - there will be many over dew, in lieu of frost ... In March there will be a startling disclosure made with 
regard to Fisheries Question, which Mr. Chamberlain will not be able to settle, owing to the Canadian cod being too largely seasoned with Yankee sauce..... ${ }^{64}$

Because of their popularity, almanacs were frequently used by various groups to 'spread the word.' Many religious denominations, notably the Catholic church in Quebec, issued their own almanacs which included detailed clergy lists, biographies and portraits of church officials, and reports on missionary work and new parishes. Photographs or illustrations of churches might also appear along with suggestions for daily prayers and readings from the Bible. The Baptists, the Wesleyan Methodists, and the Presbyterians are among the other religious denominations which issued these annual publications. The temperance movement also used almanacs to promote its message. These almanacs contained medical and personal accounts of the horrors of alcohol abuse and also provided detailed information on temperance societies.

Almanacs were also issued specifically to voice political opinion, not only in the humorous manner of the Grip, but also in a much more serious vein. A well-known example is William Lyon Mackenzie's The Caroline Almanack of $1840 .^{65}$ Along with the usual astrological notes, farmer's hints, and even a nursery catalogue, Mackenzie has crammed the calendar months and the pages between them with a detailed chronology of historical events, many relating to the Rebellion, and has even supplied 'a copious index' containing such terms as 'Burnings by the English,' 'Canadians doomed to die,' and 'Taxed at bayonet's point. ${ }^{\prime 66}$ Clearly, the almanacs were seen by Mackenzie as an important means of publicizing his political ideas. His colleague, James Lesslie, obviously shared this opinion, for he issued The People's Almanac during the I840s largely as a vehicle to promote his reformist views, particularly regarding the separation of church and state. ${ }^{67}$ Several decades later, Robert Sellar's Canadian Gleaner Almanac, published as a supplement to his Huntingdon, Quebec newspaper, championed the lot of the farmer in the I890s, urging agricultural reform and condemning government rail subsidies, and stating that 'public debt means poverty to the farmer. ${ }^{\prime 68}$ The fact that these men and others chose the almanac as a means of conveying their opinions to their fellow Canadians is a strong testament to their faith in the power of this humble annual publication.

For perhaps the same reasons, almanacs were also widely used for advertising purposes, particularly for such products as patent medicines. There are many colourful and amusing examples. Burdock Blood Bitters Almanac and Key to Health, ${ }^{69}$ Mother Siegel's Almanac / Almanach Mère Siegel, ${ }^{70}$ and the Victoria Illustrated Almanac ${ }^{71}$ produced by the Victoria 
Chemical Company, were among the most popular of the patent medicine titles. In addition to including calendars, astrological information, and perhaps some household and agricultural hints, these almanacs contained many advertisements for the various cure-alls being peddled, and testimonials from rejuvenated customers. Mother Siegel's Syrup or Shaker Extract of Roots, for example, was claimed to cure such varying ailments as liver disorders, rheumatism, worms, fever and 'female diseases.' These almanacs were frequently distributed to pharmacies across the country. A blank space was left on the wrapper so that an individual drug store could have its name printed under the words 'Compliments Of,' before distributing the almanacs free to its customers. In addition to patent medicines, examples are known of almanacs being used to promote the products of sewing machine manufacturers, hardware stores, and household dyes. The fact that many advertisers continued to use almanacs as promotional materials well into the twentieth century confirms the popularity and apparent effectiveness of the almanac in conveying information.

This admittedly cursory examination of the history and contents of Canadian almanacs has, it is hoped, emphasized the major selling-point of these publications, not only to their original audiences, but also to their twentieth-century readers. The real strength of almanacs lies in the fact that so much diverse information is packaged into one compact booklet. This greatly facilitates many types of research. For example, if one wished to compare the number of physicians in Saint John, Halifax, and Montreal for a given year, looking at almanacs from those cities would be an expeditious way of obtaining those figures. While also very helpful for general studies of such topics as agriculture, military and religious history, and domestic sciences, the almanacs' detailed listings of municipal information make them invaluable to local historians who can easily document the development of an area by examining consecutive almanacs published in that particular city or region. Clearly set out in their pages are the names and terms of public officers, the appointment of commissioners to oversee the construction of roads, jails, and hospitals, lists of churches, schools, libraries, fire departments, and newspapers. Almanacs can succinctly and accurately answer questions relating to all of these topics. While their weather prognostications may have been fabricated, there is strong indication that almanac makers made every effort to be as correct and up to date as possible when compiling factual information for their publications. It was not uncommon for publication to be delayed in order that the latest information could be inserted, a fact which is mentioned in many almanac prefaces. Richard Stanton went so far as to print a new title-page and add an additional note to his Upper Canada Almanac and Farmer's Calendar for ... 1831 after word of the death of George IV reached Canada, even though 
the printing of his almanac had already been completed. ${ }^{72}$ This reliability was essential in attracting and maintaining a loyal readership in order to compete with rival almanacs. The almanac compiler's final reward for his pains would no doubt be to know that his publication was still being consulted in the twentieth century.

The story of almanacs in Canada is in many ways the story of this country itself. The work of clever, persistent people supplying their fellow citizens with information, entertainment, and even inspiration, these publications are a rich legacy left to us by our early printers and publishers whose hard work and ingenuity at compiling the almanacs becomes all the more admirable the longer one delves into their fascinating pages.

NOTES

I Bernard Capp, Astrology and the Popular Press: English Almanacs 1500-1800 (London and Boston: Faber \& Faber, I979).

2 Marion Barber Stowell, Early American Almanacs: The Colonial Weekday Bible (New York: Burt Franklin, r977).

3 Geneviève Bollème, Les Almanachs Populaires aux XVII et XVIII Siècles: Essai d'Histoire Sociale (Paris: Mouton, I969).

4 'Canadian Almanachs / Almanachs Canadiens, I765-1900,' a project initiated by Dorothy Ryder and funded by the Social Sciences and Humanities Research Council of Canada, is being prepared for publication by Patricia Fleming, Anne Dondertman and Judy Donnelly.

5 Stowell, p.7.

6 Ibid, p. 8.

7 Ibid.

8 Gesamtkatalog der Wiegendrucke (Leipzig: Verlag von Karl W. Hiersevaaun, I935-40), I 285 .

9 Frederick R. Goff, Incunabula in American Libraries: A Third Census of Fifteenth-Century Books Recorded in North American Collections (Millwood, N.Y.: Kraus Reprint Co., I973), R-92.

Io Stowell, p. Io.

I I Ibid, p.xiv.

I 2 Marie Tremaine, A Bibliography of Canadian Imprints, 1751-1800 (Toronto: University of Toronto Press, I952), 57.

I3 Quoted in ibid.

I4 Tremaine II9.

I5 Tremaine 446.

I6 Tremaine III3.

I7 Prince Edward Island Calendar for ... 1829 (Charlottetown: George T. Haszard). A reference to an earlier P.E.I. almanac (issued for the year I 8 I 5, printed at the Gazette Office) was sent to CIHM and passed along to the compilers of Canadian 
Almanacs / Almanachs Canadiens; however, no copies of this almanac have been located as of Sept. I991.

I8 Agnes O'Dea, A Bibliography of Newfoundland (Toronto: University of Toronto Press in association with Memorial Univerity, I986), Ar73.

I9 Winnipeg Directory and Manitoba Almanac for $1876 \ldots$ Postal Guide and Handbook of General Information (Winnipeg: Cook \& Fletcher).

20 The Regina Almanac (Regina, N.w.T.: The Leader Co., I 888).

2 I The Calgary Tribune Almanac for ... 1888 (Montreal: Gazette Printing Co.).

22 Barbara J. Lowther, A Bibliography of British Columbia: Laying The Foundations 1849-1899 (Victoria: University of British Columbia, I968), 265.

23 Tremaine 122.

24 A Bibliography of Canadiana (Toronto: Toronto Public Library, I934), 6I 5.

25 Tremaine 122.

26 Iakentasetatha Kahnawakeha (Montreal: L.A. Bergeron, I898).

27 Cree Almanack: Naheyowawe Pesimoo Mussinuhikum (Oonikup, The Pas, Cumberland, N.w.T.: Rev. Joseph Reader, I888).

28 Tremaine 503.

29 Der Canada Calendar (Berlin: Heinrich Eby et al., I 84[I?]-1920).

30 Tremaine 548.

3 I Belcher's Farmer's Almanac for ... 1853 (Halifax: C.H. Belcher, I85[2]), copy in Special Collections, Hamilton Public Library, Hamilton, Ont., and An Almanack for the Year ... (Halifax: John Howe \& Son, I790-I82 I), copies at National Archives of Canada, are examples.

32 Patricia Fleming, Upper Canada Imprints 1801-1841 (Toronto: University of Toronto Press, I988), 599.

33 Canadian Farm and Home Almanac (Lewiston, Maine: Almanac Publishing Co. and Paperjacks Ltd., I986), p. I9.

34 Almanach des Cercles Agricoles ... 1898 (Montreal: J.B. Rolland \& Fils), pp. 90-I.

35 The Nova Scotia Family Almanack and Register for 1851 (Halifax: English \& Blackadar), p. [2].

36 Smith's Planetary Almanac and Weather Guide ... 1886 (Montreal: Walter H. Smith), pp. 3-4.

37 Ibid, I 887, p. [3].

38 Tremaine 446.

39 Belcher's Farmer's Almanac for ... 1853 (Halifax: C.H. Belcher), pp. 84-5.

40 The Upper Canada Almanack and Provincial Calendar for ... 1831 (York: R. Stanton), pp. 68-9 (Fleming 585).

4I Ibid, p. 69 (copy in Special Collections, Hamilton Public Library).

42 The Montreal Almanack or Lower Canada Register for 1830 (Montreal: Robert Armour), p. I6r.

43 The Nova Scotia Calendar for Town and Country ... 1828 (Halifax: P.J. Holland).

44 An Almanack for the Year of Our Lord 1829 (Saint John: Henry Chubb), p. 56. 
45 The British Columbia Almanac ... 1896 (Victoria: Colonist Printing \& Publishing Co.), p. 2 I (Lowther I I 47).

46 The Montreal Almanack and Book of General Reference and Information for 1846 (Montreal: Donoghue and Mantz), p. 6I.

47 Tremaine 368, p. 57.

48 Ibid.

49 Ottawa Almanac and Dominion Guide 1875 (Ottawa: A.S. Woodburn), pp. 33-4.

50 The Newfoundland Almanack ... 1861 (St. John's: Joseph Woods), p. 50.

5 I Ibid, I858, p. 4 I.

52 Belcher's Farmer's Almanack ... 1841 (Halifax: C.H. Belcher), p. 39.

53 Barnes's New Brunswick Almanack ... 1882 (Saint John: Barnes and Company), p. I30.

54 The Canadian Mercantile Annual ... 1874 (Montreal: Dun Wiman \& Co).

55 Bryson's Canadian Farmer's Almanac ... 1849 (Montreal: Campbell Bryson), pp. $4 \mathrm{I}-53$.

56 The Upper Canada Farmers' and Mechanics' Almanac ... 1840 (Toronto: Eastwood \& Co.), pp. 28-9 (Fleming I384).

57 Miller's Canadian Farmer's Almanac ... 1870 (Montreal: R. \& A. Miller), pp. 46-7.

58 The British American Almanack of the Motions of the Luminaries ... 1792 (Saint John: C. Sower and J. Ryan), p. I7 (Tremaine 688).

59 The Canadian Family Almanac ... 1893 (Berlin: Berlin Publishing Co.), pp. 7 I-2.

60 The Montreal Almanack ... 1842 (Montreal: H.C. M'Leod), p. 3.

6I Almanack for the Year of our Lord ... 1825 (Halifax: Henry Chubb), pp. 47-8.

62 Etrennes Mignones [sic] pour ... 1799 (Quebec: Nouvelle Imprimerie), pp. 22-4.

63 Alex. McGibbon's Dominion Almanac for 1868 (Montreal: Alex McGibbon), p. I 5.

64 Grip's Comic Almanac (Toronto: Grip Printing and Publishing Co.).

65 The Caroline Almanack and American Freeman's Chronicle for 1840 (Rochester: William Lyon Mackenzie at the Gazette Office).

66 Ibid., pp. I I6-20.

67 The People's Almanack (Toronto: Lesslie Brothers Printers \& Publishers).

68 Canadian Gleaner Almanac for ... 1898 (Huntingdon: Robert Sellar).

69 Burdock Blood Bitters Almanac and Key to Health (Toronto: T. Milburn \& Co.).

70 Mother Siegel's Almanac / Almanach Mère Siegel (Montreal: A.J. White \& Co.).

7 I Victoria Illustrated Almanac (Toronto: Victoria Chemical Co.).

72 Fleming 508. 